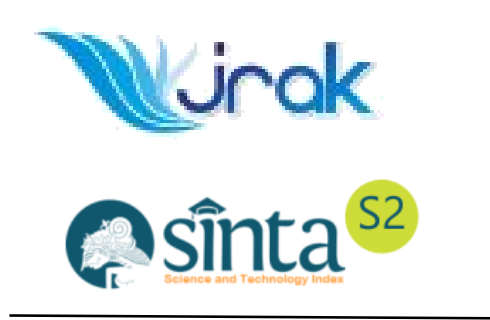

Website:

ejournal.umm.ac.id/index.php/jrak

*Correspondence:

bani-alkausar@vokasi.unair.ac.id

DOI: $\underline{10.22219 / \text { irak.v11i1.15610 }}$

Citation:

Kawakibi, F.B., Lasmana, M.S., \& Alkausar, B. (2021). Corporate

Governance And Tax

Aggressiveness: Agency Theory

Relationship. Jurnal Reviu Akuntansi

Dan Kenangan, 11(1), 138-149.

Article Process

Submitted:

February 15, 2021

Reviewed:

March 29, 2021

Revised:

April 30, 2021

Accepted:

May 1, 2021

Published:

May 5, 2021

Office:

Department of Accounting

University of

Muhammadiyah Malang

GKB 2 Floor 3.

Jalan Raya Tlogomas 246,

Malang, East Java,

Indonesia

P-ISSN: 2615-2223

E-ISSN: 2088-0685
Article Type: Research Paper

\section{CORPORATE GOVERNANCE AND TAX AGGRESSIVENESS: AGENCY THEORY RELATIONSHIP}

\author{
Farel Badar Kawakibi ${ }^{1}$, Mienati Somya Lasmana ${ }^{1}$, Bani \\ Alkausar $^{2^{*}}$ \\ Afiliation: \\ ${ }^{1}$ Accounting Departement, Faculty of Economics and Business, \\ Universitas Airlangga, Surabaya, East Java, Indonesia \\ ${ }^{2}$ Business Departement, Faculty of Vocational Studies, Universitas \\ Airlangga, Surabaya, East Java, Indonesia
}

\section{ABSTRACT}

The study aimed to provide evidence of whether corporate governance can lower the tendency of companies to perform tax aggressiveness. The term of Tax Aggressiveness was used to further expand the meaning of the act of minimizing taxes by companies. The cash effective tax rate was used as an indicator of the tax aggressiveness of companies. Meanwhile, corporate governance was measured by the institutional ownership, independent commissioner, audit committee, and audit quality. Samples used were the manufacturing companies listed on the Indonesia Stock Exchange (BEI) in 2018. Results of the 97 samples observed indicated that independent commissioners proved to be able to suppress the tendency of companies to commit Tax Aggressiveness; meanwhile, the institutional ownership, audit committee, and audit quality was not proven. The existence of the independent commissioners is able to influence the decisions in creating policies that are set by the management, so the management does not perform an opportunistic action that would benefit the management including committing Tax Aggressiveness.

KEYWORDS: Audit Committee; Audit Quality; Corporate Governance; Independent Commissioners; Institutional Ownership; Tax Aggressiveness. 


\section{INTRODUCTION}

Corporate Governance and Tax Aggressiveness tax are phenomena that are associated with conflict of agency in the company. The company as one of the mandatory taxpayers has an obligation to pay taxes based on the revenue that is generated. Payment of tax by the company will reduce the profit net. In this case, it is contrary to the purpose of the companies to maximize profits for the sake of achieving the goal of the company (the interests of investors) and increase the sustainability of their business. The company will always try to minimize its tax burden through tax planning efforts. Attempt to minimize the burden of taxes through planning taxes can be done legally or illegally by taking advantage of loopholes in the law of taxation (gray area) which are known by the term 'Tax Aggressiveness'. The action of Tax Aggressiveness that is committed by companies will pose a risk for companies, such as sanctions taxes and the decline of company reputation. Those risks will be a major problem that will be faced by the companies later if they are proven to be guilty. This will give disadvantages for the owner of the company (investors) due to the behavior of opportunistic managers to maximize corporate profit by committing Tax Aggressiveness.

Agency theory refers to the contractual relationship between the agent (manager) and the principal (owner of the company). Agents perform specific tasks to the principal, and the principal has the obligation to give a reward to the agent (Hendriksen and Breda, 1992). Jensen and Meckling (1976) state that an agency relationship is a contract between one or several people (giver of work or principal) who employs another person (the agent) to perform a number of services and provide authority in decision-making. Principal and agent are assumed as parties who have the ratio of the economy and are motivated by the personal interests that, even though there is a contract, the agent will not perform the best for the sake of the owners.

Conflicts of agency arise in the relationship between the principal and the agent if there is no balanced information between them (asymmetry information). It is caused by the fact that the investor (principal) does not necessarily have the information that is similar to the management (agent) who has direct access to the business activities. Thus, the agent is considered to have more complex information than the principal. This tends to cause the agent to commit dysfunctional behaviors. One of them is manipulating the data in the statement of financial, so it meets the expectations of the principal; even though, it does not describe the actual condition of the company (Pajriyansyah and Firmansyah, 2016). The asymmetry of information provides an opportunity for management to use their policy in managing the information the accounting including policies to commit Tax Aggressiveness for the sake of company's profit as well as personal advantages (Scott, 2009).

The supervision of the management needs to be conducted to avoid actions that can harm the company. Good corporate governance is a set of rules that regulates the relationship between the stockholder, administrators (managers) of the company, the creditors, governments, employees, and the holders of other internal and external interest that are related to their rights and obligations or, in other words, a system that sets up and controls the company (FCGI, 2001). There are two mechanisms in the implementation of the supervision of corporate governance, namely the supervision of internal and external. Supervision of the internal uses the structure and the internal system to control of

11.1 companies such as Annual General Meeting of Shareholders (AGMS), the composition of the board of directors, and the proportion of the board of commissioners. The mechanism 
of external corporate governance is a way to control the company through the structure and the external system. One of the examples is the role of institutional shareholders.

Institutional ownership is one of the components of good corporate governance to minimize the agency conflicts between the principal and the agent (C.Jensen and H.Meckling, 1976). Institutional ownership is the percentage of ownership of stocks that are owned by institutions, governments, companies, and others. These institutions invested money in a company to get revenues. Since the company has a responsibility to the shareholders, the institutional investors have an incentive to ensure that the management company makes wise decisions to prosper the owner of the company (Damayanti and Susanto, 2015). Research from Ariawan and Setiawan (2017) and Marfirah and Syam (2016) showed that institutional ownership has a positive effect on tax avoidance. The majority shareholders can influence decisions and policies that are taken by the management company. The higher the institutional ownership, the less tax avoidance can be performed (Okrayanti et al., 2017). Based on the explanation of institutional ownership, the following is hypothesis 1:

\section{$\boldsymbol{H}_{1}$ The ownership has a negative effect on the Tax Aggressiveness}

The leadership system of a limited company in Indonesia is divided into two, namely the board of directors and the board of commissioners. The Board of directors and board of commissioners have their own duty and function in the company, but they must have the same vision and mission for the sake of the continuity of the company in the future. Article 20 paragraph (2) of the Financial Services Authority Regulation Number 33 / POJK.04 / 2014 concerning the Board of Directors and Board of Commissioners of Issuers or Public Companies states that the board of commissioners consists of 2 (two) members of the board of commissioners, and one of them is an independent commissioner. The number of members of the independent commissioner is at least $30 \%$ of the total members of the board of commissioners. The Board of independent commissioners is not allowed to have a relationship of business, family, or others that may disrupt the integrity commissioner, so the monitoring of the company can be strengthened.

The existence of independent commissioners is very important considering their duties as the supervisors of the management. Conflicts agency that occurs between the shareholders and the management can be minimized by the presence of the independent commissioner as a supervisor as well as a party that mediates if the conflict occurs. A study that was done by Marfirah and Syam (2016) and Armstrong et al. (2015) found that the independent commissioner can decrease the tendency of companies to commit Tax Aggressiveness. Based on the explanation of the independent commissioners, the following is hypothesis 2:

$\boldsymbol{H}_{2}$ Independent commissioners have a negative effect on Tax Aggressiveness.

The decision of the Chairman of BAPEPAM (Capital Market Supervisory Agency and Financial Institution) number Kep-29/PM/2004 regulations no.IX.1.5 on the Establishment and Guidelines for Implementation of the Working Committee on Audit states that the audit committee is a committee that was formed by the Board of Commissioners to carry out their duties and functions. The main task of an audit committee is to create good corporate governance in the company through the supervision of the problem that is associated with the financial policy, accounting, and company internal control. The audit committee is expected to strengthen the supervision, especially related to the financial problems of companies that are very significant for the investors. The existence of the audit committee can influence decisions and policies that are set by

JRAK

11.1 
the management. Thus, the management does not commit an opportunistic action that would benefit the management including tax avoidance.

The number of the company audit committee has a positive effect on the level of tax avoidance (Marfirah and Syam, 2016). The number of the audit committee should be in accordance with the provisions that apply. If the company has a number of the audit committee that is less than the number of the required regulation, the supervision will weaken and it affects the decisions that are made by the management, including the establishment of policies that is related to taxes. Based on the explanation of the audit committee, the following is hypothesis 3 :

\section{$\boldsymbol{H}_{3}$ The audit committee has a negative effect on Tax Aggressiveness}

In addition to the audit committee, audit quality also is one of the components of good corporate governance. According to Dewi and Jati (2014), audit quality is every possibility that may occur during the audit process in a company and the finding of errors that occur by presenting it in a financial report which has been audited. Transparency is the key to an audit process. Quality audits can be seen from how big the reputation of the Public Accountant Firm (KAP) which audited the company. Some references stating that companies are audited by the big four (Ernst \& Young - EY, Deloitte, KPMG, and PricewaterhouseCoopers - $\mathrm{PwC}$ ) has lower fraud level than the company that is audited by other than the big four; thus, the real value of a company can be reflected (Annisa and Kurniasih, 2012).

Results of the study showed that the audit quality impacts positively on tax avoidance (Annisa and Kurniasih, 2012). Companies that are audited by the Big Four accounting firm tends to show the actual value of the company. The more qualified a company is, the more likely the company does not commit things that can damage its reputation, such as tax evasion. Companies that are audited by the Big Four will find it difficult to commit tax avoidance (Marfirah and Syam, 2016). Based on the explanation of audit quality, the following is hypothesis 4 :

\section{$\boldsymbol{H}_{4}$ Audit quality has a negative effect on tax aggressiveness.}

The previous studies showed various results depending on the influence of the institutional ownership, independent commissioner, audit committee, and audit quality against tax avoidance. There is a positive influence on tax avoidance (Ariawan and Setiawan, 2017; Marfirah and Syam, 2016; Victor Pattiasina et al., 2019), but there is no effect in the studies conducted by Arianandini and Ramantha (2018), Sandy and Lukviarman (2015), and Damayanti and Susanto (2015).

Previous studies have identified several companies' opportunistic actions to minimize the $\operatorname{tax}$ burden as tax avoidance. The current study chose to use the term of Tax Aggressiveness rather than tax avoidance which includes the more general definition that describes the actions to minimize the burden of taxes which include the action of tax evasion and the action that is not related to tax evasion (Frank et al., 2009). Based on the development of hypotheses, the purpose of the study was to provide empirical evidence on the roles of corporate governance to minimize the behavior of opportunists manager in committing Tax Aggressiveness. In addition, in this study, different tax aggressiveness measures are used which is proxy Cash Effective Tax Rate (CETR) which describes the company's deferred tax strategy (Hanlon and Heitzman, 2010) 


\section{METHOD}

This study used a purposive sampling method which is a method of determining the sample with certain considerations (Anshori and Iswati, 2009:105). The population that was used in the current research was manufacturing companies that were listed on the Indonesia Stock Exchange (BEI) in 2018 because previously the government had issued a tax amnesty policy. Furthermore, the reason for choosing this population was because manufacturing companies are companies whose business activities are large, starting from purchasing raw materials to processing them into finished goods that are ready to be sold in the market and related to the taxation aspect.

Figure 1.

Framework of Hypotheses

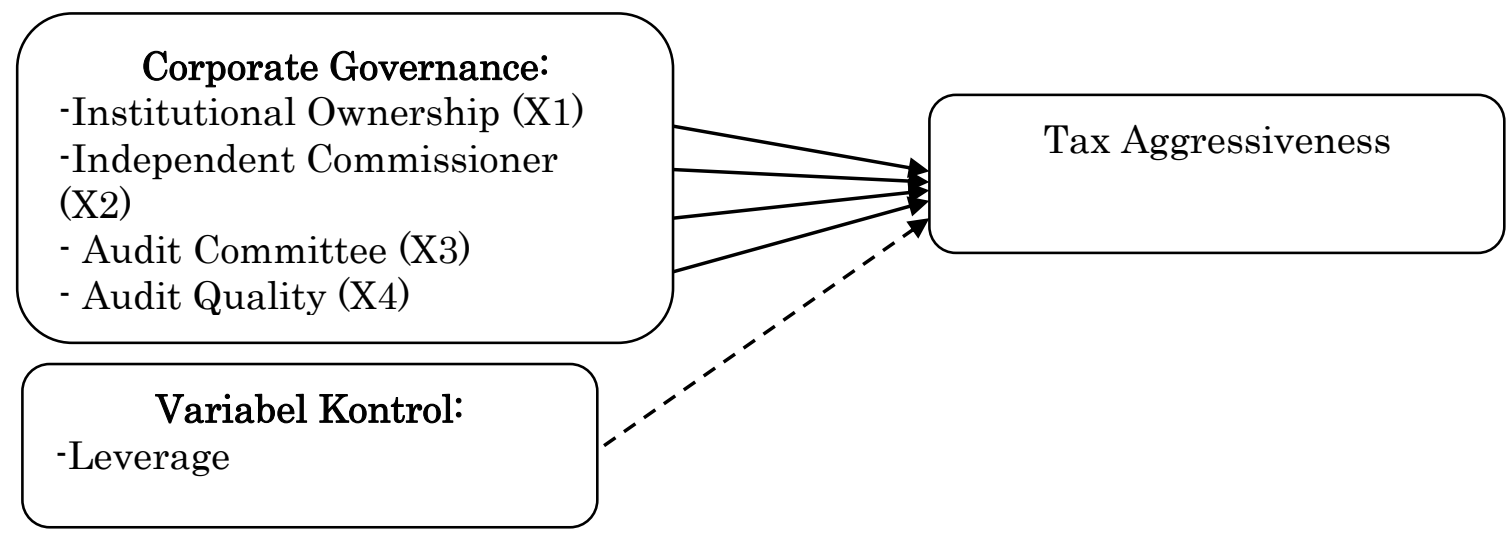

The sample selection was based on the purposive sampling method. The criteria for the sample were used, were as follow:

No Criteria

1 The manufacturing companies were listed on the Stock Exchange during the period of 2018

2 The manufacturing companies published annual reports and presented the complete information that was required in the research which was the total debt, total asset, number of shares owned by institutions, the number of outstanding shares, the number of independent commissioners, the number of commissioners, the number of the audit committee, the firm that did the audit of the company, the amount of company paid tax in the cash flow statement, and profit before tax income during the period of 2018

3 The manufacturing companies published reports of finances for the period that ended on the date of 31 December on the Stock Exchange during the period of 2018

Table 1.

4 The manufacturing companies did not suffer a loss during the period of 2018

Sample

5 Manufacturing companies have a Cash Effective Tax Rate (CETR) of less than one 
Tax Aggressiveness is an effort that is made by the company to minimize or negate the burden of taxation legally or illegally. Tax aggressiveness can be calculated through cash ETR (effective tax rate) because it shows the condition of company tax payments (Hanlon and Heitzman, 2010). Calculations were done by comparing the burden of taxes that are paid in cash and the profit before tax. The smaller value of CETR, the more aggressive the company against tax.

Institutional ownership is the percentage of ownership of outstanding shares owned by the institution. The institution includes companies or governments which manage funds on behalf of others. The current study used the measurement of institutional ownership based on research conducted by Marfirah and Syam (2016) by comparing the shares owned by institutions and the number of outstanding shares.

An Independent Commissioner is a member of the board of commissioners who do not have a relationship and affiliation with the company, including the family relationship with directors, shareholders, members of the board of commissioners, or the other relationships that can affect the independence of the board of commissioners (KNKG, 2006). The Board of commissioners is measured by the percentage of the board of independent commissioners compared to the number of the entire board of commissioners of the company. The information about this can be obtained from the annual company reports (Marfirah and Syam, 2016). The audit committee is a committee that was formed by the Board of Commissioners to carry out their duties and functions. The audit committee in the company consists of at least three people. The audit Committee was measured by seeing the number of the existing audit committee in the company (Marfirah dan Syam, 2016).

Marfirah and Sham (2016) in their research used a dummy variable to measure the quality of the audit. The company that was audited by the Big Four, namely Ernst \& Young - EY, Deloitte, KPMG, and PricewaterhouseCoopers - PwC was given the value of 1 while the companies audited by non-Big Four were given a value of 0 .

The equation model in this study:

$$
\mathrm{AGP}_{\mathrm{t}}=\alpha+\beta_{1} \mathrm{INST}_{\mathrm{t}}+\beta_{2} \mathrm{COMMISSION}_{\mathrm{t}}+\beta_{3} \mathrm{COMMITTEE}_{\mathrm{t}}+\beta_{4} \mathrm{AUD}_{\mathrm{t}}+\beta_{5} \mathrm{LEV}_{\mathrm{t}}+\varepsilon
$$

Description:

$\alpha$

AGP

INST

KOMIS

COMMITTEE

AUD

LEV

$$
\begin{aligned}
& =\text { Constant } \\
& =\text { Tax aggressiveness as measured by CETR } \\
& =\text { institutional ownership as measured by } \\
& =\text { independent commissioner as measured by } \\
& =\text { the audit committee as measured by } \\
& =\text { audit quality as measured by } \\
& =\text { Leverage as measured by the debt ratio }
\end{aligned}
$$

\section{RESULTS AND DISCUSSION}

Table 2 shows the results of descriptive statistics. Institutional ownership (INST) has the 11.1 lowest value of 0.0000 and the highest value of 0.90 . The independent commissioner (KOMIS) has the lowest value of 0.0000 and the highest value of 1 . The audit committee (COMMIT) has the lowest value of 0 and the highest value of 5 . Audit quality (AUD) has 
the lowest value of 0 and the highest value of 1 . The use of numbers 0 and 1 in this variable is used as a dummy variable, where 0 indicates the company being audited by the firms that were not included in the Big Four, and figure 1 shows the companies were audited by the Big Four accounting firm. Overall, the standard deviation is lower than the average value which indicates that the data are homogeneous, and values between samples are relatively the same.

\begin{tabular}{lccccc}
\hline & N & Lowest & Highest & Average & $\begin{array}{c}\text { Std. } \\
\text { Deviation }\end{array}$ \\
\hline DR & 97 & .09 & 0.90 & .4155 & .1883 \\
INST & 97 & .00 & 1 & .6836 & .2622 \\
KOMIS & 97 & .29 & 1 & .3987 & .1060 \\
KOMIT & 97 & 0 & 5 & 3.01 & .4893 \\
AUD & 97 & 0 & 1 & .3505 & .4796 \\
CETR & 97 & 0 & .68 & .2654 & .1355 \\
Valid N (listwise) & 97 & & & & \\
\hline
\end{tabular}

Based on table 3 , the model equation is obtained as follows:

CETR $=0.321+0.032 \mathrm{INST}+0.012 \mathrm{KOMIS}-0.005 \mathrm{KOMITE}-0.033 \mathrm{AUD}-0.111 \mathrm{LEV}$

Equation models explain the influence of independent variables towards the dependent variable with the constant value $\alpha$ of 0.321 , showing that if the other variable is - 0 , then the value of CETR is at 0.321 . The coefficient of the regression variable of institutional ownership (X1) is 0.032 . The coefficient of the regression variable of independent commissioner (X2) is 0.012. The coefficient of the regression variable of the audit committee $(\mathrm{X} 3)$ is -0.005 . The coefficient of the regression variable of audit quality (X4) is 0.033 . The coefficient of the regression variable of leverage (Control) is -0.111 .

\begin{tabular}{|c|c|c|c|}
\hline \multirow[t]{2}{*}{ Model } & \multicolumn{2}{|c|}{ Unstandardized Coefficients } & \multirow{2}{*}{$\begin{array}{c}\begin{array}{c}\text { Standardized } \\
\text { Coefficients }\end{array} \\
\text { Beta }\end{array}$} \\
\hline & $\mathbf{B}$ & Std. Error & \\
\hline (Constant) & .321 & .113 & \\
\hline INST & .032 & .075 & -.154 \\
\hline KOMIS & .012 & .056 & .062 \\
\hline KOMITE & -.005 & .134 & -.009 \\
\hline AUD & -.033 & .029 & -.018 \\
\hline LEV & -.111 & .031 & -.115 \\
\hline
\end{tabular}

Table 3.

Regression 


\begin{tabular}{cccc}
\hline & $\mathbf{t}$ & Sig. & \\
\cline { 1 - 3 } (Constant) & 2.849 & .005 & \\
INST & .570 & .570 & \\
KOMIS & 1.088 & .040 & Table 4. \\
KOMITE & -.171 & .865 & Statistical \\
AUD & -1.048 & .297 & Test \\
LEV & -1.477 & .143 & S \\
\hline
\end{tabular}

The hypothesis testing result of the institutional ownership variable has a regression coefficient $\beta 2$ of 0.032 . This indicates that if the value of institutional ownership is increased by one point, it will increase the value of CETR by 0.032 and has an impact on the decrease in the Tax Aggressiveness for 0.032 by assuming other variables are constant. The t-test shows a value of 0.570 which is greater than 0.05 . It showed that the variable of institutional ownership does not have a significant effect on the Tax Aggressiveness at the level of significance $\alpha=5 \%$, so the hypothesis is rejected. The positive coefficients mean the higher number of percentage of shares owned by institutions, the smaller possibility of the Tax Aggressiveness committed by the company since the CETR value is increasing.

Institutional ownership is the percentage of shares owned by institutions, governments, companies, and others. The institutions infuse capital into a company to obtain the results as investments. The institutions that have the investments will carry out supervision to minimize the agency conflicts since the company cannot make policies that favor one party or a specific group (Arianandini and Ramantha, 2018). However, the results of the study showed that the number of institutional ownership whether it is small or big, is not the factor that can minimize the Tax Aggressiveness. Supervision of institutional ownership emphasizes how the management can give profits and benefits to the owners (Arianandini and Ramantha, 2018). The acts of minimizing the tax burden legally are considered to be beneficial for the institutions, so they do not influence the management to avoid this action (Damayanti and Susanto, 2015). This is in line with the studies conducted by Arianandini and Ramantha (2018), and Damayanti and Susanto (2015) which concluded that institutional ownership has no relation with tax avoidance.

The hypothesis testing result of the independent commissioner has a coefficient regression $\beta 3$ of 0,012 . This indicates that if the value of independent commissioners is increased by one point, it will increase the value of CETR by 0,012 and has an impact on the decrease in the level of Tax Aggressiveness for 0,012 by assuming other variables are constant. The ttest shows a value of 0.040 which is smaller than 0.05 . It showed that the variable of independent commissioner has a significant effect on the Tax Aggressiveness at the level of significance $\alpha=5 \%$, so the hypothesis is accepted. The negative coefficients mean that the higher number of the independent commissioner, the smaller possibility of the company committing Tax Aggressiveness since the CETR value is increasing.

The leadership system of a limited company in Indonesia is divided into two, namely the board of directors and the board of commissioners. The board of directors and the board of commissioners have their respective duties and functions. The membership structure of JRAK the board of commissioners requires that one of them is an independent commissioner or at least $30 \%$ of the total members of the board of commissioners. The existence of 11.1 independent commissioners is very important considering their duties as supervisors of the company management. Agency conflicts that occur between the shareholders and the management can be minimized by the presence of the independent commissioner as a 
supervisor as well as the party that can mediate when the conflict occurs Furthermore, the management policy on the Tax Aggressiveness action is also being supervised by the independent commissioner who has no affiliation with the company; thus, everything can be seen more objectively (Marfirah and Syam, 2016). The result showed that the independent commissioner impacts significantly on the Tax Aggressiveness.

The existence of independent commissioners is very important considering their duties as supervisors of company management. Agency conflicts that occur between the shareholders and the management can be minimized by the presence of the independent commissioner as supervisor as well as the party that can mediate when conflict occurs. It is in line with research conducted by Marfirah and Syam (2016) which stated that the independent commissioner impacted negatively on the behavior of tax avoidance. However, contrary to the research that is carried out by Victor Pattiasina et al. (2019), it is stated that an independent commissioner has no significant influence on the tax avoidance committed by a company.

The hypothesis testing result of the audit committee has a coefficient regression $\beta 4$ of 0.005. This indicates that if the value of independent commissioners is increased by one point, it will decrease the value of CETR by 0.005 and has an impact on the increase in the level of Tax Aggressiveness for 0.005 by assuming other variables are constant. The t-test shows a value of 0.865 which is greater than 0.05 . It shows that the variable of the audit committee has no significant effect on the Tax Aggressiveness at the level of significance $\alpha$ $=5 \%$, so the hypothesis is rejected. The negative coefficients mean that the higher number of the audit committee, the higher possibility of the company committing Tax Aggressiveness since the CETR value is decreasing.

The Board of commissioners forms a function that oversees the issues of the company's financial policy that is called the audit committee. The existence of an audit committee is expected to strengthen the supervising function, especially related to the company's financial problem which influences the investors' trust significantly. The existence of the audit committee can influence the decisions on the policies that are set by the management, so the management does not perform opportunistic actions that would benefit the management.

However, this is different from the results of the study which showed that the number of audit committees does not affect the Tax Aggressiveness. The number of the audit committee, whether it is big or small, is not able to guarantee the management will be more careful in determining its policy (Damayanti and Susanto, 2015). The quality of the audit committee is more important than the number of the audit committee (Damayanti and Susanto, 2015). It is contrary to the research that is done by Victor Pattiasina et al. (2019), and Marfirah and Syam (2016) who concluded that the audit committee affects tax avoidance.

The hypothesis testing result of the audit quality has a coefficient regression $\beta 5$ of -1.048 . This indicates that if the value of audit quality is increased by one point, it will decrease the value of CETR by 1.048 and has an impact on the increase in the level of Tax Aggressiveness for 1.048 by assuming other variables are constant. The t-test shows a value of 0.297 which is greater than 0.05 . It shows that the variable of the audit quality has no significant effect on the Tax Aggressiveness at the level of significance $\alpha=5 \%$, so the hypothesis is rejected. The negative coefficients mean that the higher the audit quality, the higher possibility of the company committing Tax Aggressiveness since the CETR value is decreasing.

JRAK 11.1 
It is mentioned in the explanation of article 68 paragraph (1) of Law no. 40 of 2007 concerning Limited Companies, the obligation to submit financial reports to a public accountant for auditing arises from the nature of the Company concerned. Financial reports will be believed by the investor after being audited by the Public Accountant Firm (KAP). Independent auditor who examines financial reports and gives opinions on the financial reports needs to ensure the information that is presented is relevant and presented as reasonably as possible by the company (Arens et al., 2016;169). According to Dewi and Jati (2014), audit quality is every possibility that may occur during the audit process in a company and the finding of errors that occur by presenting it in a financial report which has been audited. Transparency is the key to an audit process. Quality audits can be seen from how big the reputation of the Public Accountant Firm (KAP) which audited the company. Some references stating that companies are audited by the big four (Ernst \& Young - EY, Deloitte, KPMG, and PricewaterhouseCoopers - PwC) has lower fraud level than the company that is audited by other than the big four; thus, the real value of a company can be reflected (Annisa dan Kurniasih, 2012).

However, the results of the study found the results of the audit quality are not significant means that both companies that are audited by the Big Four accounting firms and non-Big Four accounting firms are not able to prevent companies doing the Tax Aggressiveness (Damayanti dan Susanto, 2015). As long as it does not have a bad impact on the company, both The Big Four firms and non-Big Four firms provide leeway for companies to do tax avoidance. The results support the study that is conducted by Damayanti and Susanto (2015) which states that being audited by the Big Four accounting firms and non-Big Four firms does not guarantee the company will be free of fraud.

\section{CONCLUSION}

The current study provides empirical evidence on the role of corporate governance in lowering the Tax Aggressiveness of companies in Indonesia. The measurement of corporate governance used institutional ownership, independent commissioners, audit committee, and audit quality. The results showed that the independent commissioners is proven to be able to suppress the tendency of companies to commit Tax Aggressiveness. Meanwhile, the institutional ownership, audit committe, and audit quality are not proven. The existence of the independent commissioners is able to influence the decisions in creating policies that are set by the management, so the management does not perform an opportunistic action that would benefit the management including committing Tax Aggressiveness. The limitation of the study is the non-existence of the whole corporate governance measurement, so the measurement should be conducted by using several variables. Currently, the implementation of corporate governance in Indonesia is still voluntary. Thus, in the practice, many companies have not implemented it maximally. Further study can use the implementation size of the integral corporate governance, so the mechanism role of corporate governance in pressing the manager's opportunistic action becomes more apparent.

\section{REFERENCES}

\section{REFERENCES}

Annisa, N. A., \& L. Kurniasih. 2012. "Pengaruh Corporate Governance Terhadap Tax Avoidance". Jurnal Akuntansi \& Auditing, Vol. 8, No. 2, hlm: 95-189.

Anshori, M., \& S. Iswati. 2009. Metodologi Penelitian Kuantitatif. Surabaya: Pusat Penerbitan dan Percetakan UNAIR. 
Arens, A. A., R. J. Elder, M. S. Beasley, \& Hogan. 2016. Auditing and Assurance Services an Integrated Approach. Sixteenth Edition ed: Global Edition: Pearson Education Limited.

Arianandini, P. W., \& I. W. Ramantha. 2018. "Pengaruh Profitabilitas, Leverage, dan Kepemilikan Institusional pada Tax Avoidance". E-Jurnal Akuntansi Universitas Udayana, Vol. 22, No. 3, hlm: 2088-2116.

Ariawan, I. M. A. R., \& P. E. Setiawan. 2017. "Pengaruh Dewan Komisaris Independen, Kepemilikan Institusional, Profitabilitas Dan Leverge Terhadap Tax Avoidance". E-Jurnal Akuntansi Universitas Udayana, Vol. 18, No. 3, hlm: 1831-1859.

Armstrong, C. S., J. L.Blouin, \& A. D. Jagolinzer. 2015. "Corporategovernance,incentives,andtaxavoidance". Journal of Accounting and Economics, Vol. 60, No. 1, hlm: 1-17.

BAPEPAM. 2004. Keputusan Ketua BAPEPAM nomor Kep-29/PM/2004 peraturan no. IX.1.5 tentang Pembentukan dan Pedoman Pelaksanaan Kerja Komite Audit.

C.Jensen, M., \& W. H.Meckling. 1976. "Theory of the firm: Managerial Behavior, Agency Costs and Ownership Structure". Journal of Financial Economics, Vol. 3, No. 1, hlm: 305-360.

Damayanti, F., \& T. Susanto. 2015. "Pengaruh Komite Audit, Kualitas Audit, Kepemilikan Institusional, Risiko Perusahaan Dan Return On Assets Terhadap Tax Avoidance". Jurnal Bisnis dan Manajemen, Vol. 5, No. 2, hlm.

Dewi, N. N. K., \& I. K. Jati. 2014. "Pengaruh Karakter Eksekutif, Karakteristik Perusahaan, Dan Dimensi Tata Kelola Perusahaan Yang Baik Pada Tax Avoidance Di Bursa Efek Indonesia". E-Jurnal Akuntansi Universitas Udayana, Vol. 6, No. 2, hlm: 249-260.

FCGI. 2001. Seri Tata Kelola Perusahaan (Corporate Governance): Corporate Governance (Tata Kelola Perusabaan): FCGI.

Frank, M. M., L. J. Lynch, \& S. O. Rego. 2009. "Tax Reporting Aggressiveness and Its Relation to Aggressive Financial Reporting". THE ACCOUNTING REVIEW, Vol. 84, No. 2, hlm: 467-496.

Governance, K. N. K. 2006. Pedoman Umum GCG Indonesia. Jakarta Komite Nasional Kebijakan Governance.

Hanlon, M., \& S. Heitzman. 2010. "A review of tax research". Journal of AccountingandEconomics, Vol. 50, No. 1, hlm: 127-178.

Hendriksen, E. S., \& M. F. V. Breda. 1992. Accounting Theory. 5th ed. USA: Irwin Inc.

Keuangan, O. J. 2014. Peraturan Otoritas Jasa Kenangan Nomor 33/POJK.04/2014 Tentang Direksi dan Dewan Komisaris Emiten atau Perusahaan Publik.

Marfirah, D., \& F. Syam. 2016. "Pengaruh Corporate Governance Dan Leverage Terhadap Tax Avoidance Pada Perusahaan Manufaktur Yang Terdaftar Di Bursa Efek Indonesia (Bei) Tahun 2011-2015". Jurnal Ilmiah Mahasiswa Ekonomi Akuntansi JIMEKA), Vol. 1, No. 2, hlm: 91-102.

Okrayanti, T. Y., S. W. Utomo, \& E. Nuraina. 2017. "Pengaruh Karakteristik Perusahaan Dan Corporate Governance Terhadap Tax Avoidance (Studi Pada Perusahaan 
Manufaktur Di Bei)". The 9th FIPA: Forum Ilmiah Pendidikan Akuntansi, Vol. 5, No. 1, hlm: 804-817.

Pajriyansyah, R., \& A. Firmansyah. 2016. "Pengaruh Leverage, Kompensasi Rugi Fiskal Dan Manajemen Laba Terhadap Penghindaran Pajak". Jurnal Politeknik Kenangan Negara, Vol., No., hlm.

Sandy, S., \& N. Lukviarman. 2015. "Pengaruh Corporate Governance Terhadap Tax Avoidance: Studi Empiris Pada Perusahaan Manufaktur". Jurnal Akuntansi dan Auditing Indonesia, Vol. 19, No. 2, hlm: 85-98.

Scott, W. R. 2009. Financial Accounting Theory 5th Edition. 5th ed.

Victor Pattiasina, M. H. T., A. P. Agustinus Numberi, \& S. Temalagi. 2019. "Capital Intensity and Tax Avoidance: A Case in Indonesia". International Journal of Social Sciences and Humanities, Vol. 3, No. 1, hlm: 58-71. 